Original Research Paper

\title{
The Effect of Health Education on Tuberculosis Case-Finding Based on Advocacy, Communication and Social Mobilization (ACSM) Movement in Majene District, West Sulawesi, Indonesia
}

\author{
${ }^{1}$ Muhammad Syafar, ${ }^{2}$ Muhammad Ikhsan, ${ }^{1}$ Indra Fajarwati Ibnu and ${ }^{3}$ Rachma Rahim \\ ${ }^{1}$ Department of Health Education and Behavioral Science, Faculty of Public Health, \\ Universitas Hasanuddin, Makassar, Indonesia \\ ${ }^{2}$ Department of Biostatistics, Faculty of Public Health, Universitas Hasanuddin, Makassar, Indonesia \\ ${ }^{3}$ Public Health Science, Graduate School, Universitas Hasanuddin, Makassar, Indonesia
}

Article history

Received: 25-11-2018

Revised: $27-12-2018$

Accepted: 04-02-2019

Corresponding Author:

Muhammad Syafar

Faculty of Public Health,

Universitas Hasanuddin, Makassar,

Indonesia

Email:muhsyafar.unhas@gmail.com

\begin{abstract}
This research aimed to determine the effect of tuberculosis (TB) active case-finding interventions based on Advocacy, communication and social mobilization (ACSM) movement toward housewives' knowledge at the work area of Banggae I Community Health Center, Majene District, West Sulawesi, Indonesia. Quasi-experimental one group pretest and posttest design was used in this research. Participants of the research were selected by inclusive criterias. The data were analyzed by paired $T$-test with significancy level 0.05 . There was a decrease on several questions related to advocacy efforts in TB control. The paired T-test's result showed that there was association between the intervention activities and knowledge of TB information, advocacy efforts, as well as communication and social mobilization related to TB case-finding and prevention $(p=0,005)$. The housewives' knowledge significantly rise after the $\mathrm{TB}$ active case-finding interventions. It was recommended to do the further training focusing on advocacy and communication skills as well as initiate a group that concern to TB control.
\end{abstract}

Keywords: Tuberculosis Case-Finding, Intervention, ACSM

\section{Introduction}

Tuberculosis (TB) is still one of the world's public health problems. Globally, the number of TB patients in 2017 reach 10 million cases (WHO, 2018). The world data shows that the rate of $\mathrm{TB}$ incidence was decreased only $1.5 \%$ from 2014 to 2015 , with an acceleration of 4 $5 \%$ in 2020 and estimated 480,000 new cases of multidrug resistant TB (MDR-TB). Although the number of TB deaths decreased by $22 \%$ between 2000 and 2015 , TB is still remain as one of the top ten worldwide's causes of death (WHO, 2018).

Data from WHO (2018) shows that Indonesia stands on the fourth ranked as a country with highest TB cases in the world, below Africa (72\%), India (27\%) and China (9\%). In Indonesia, TB is in the fourth position as the top causes of death after ischemic heart diseases and diabetes with the distribution based on the sex type of TB death in men is higher than the women (Kementerian Kesehatan RI, 2015). Based on the Indonesia National
Health Survey year 2013, it is known that the average prevalence of pulmonary $\mathrm{TB}$ is $0.4 \%$ with the five highest provinces being West Java $(0.7 \%)$, Papua $(0.6 \%)$, DKI Jakarta $(0.6 \%)$, Gorontalo $(0.5 \%)$, Banten $(0.4 \%)$ and West Papua (0.4\%) (Balitbangkes RI, 2013). Therefore, as a form of Indonesia's commitment in TB control, the Directly Observed Treatment Short-course (DOTS) strategy recommended by WHO has been implemented and expanded gradually to each health service unit (Kementerian Kesehatan RI, 2011).

TB case finding is the first step in TB control (Myint et al., 2017; Zachariah et al., 2003). All this time, the TB case findings in Indonesia have been holding passively by waiting for TB patients to come to the community health care centers. For several years this method has not reached the target. Some studies state that the improvements in case findings relate to the knowledge, attitudes and motivation, either from the patients or health officers (Ayles et al., 2013; Sumartini, 2014; Sutarno and Utama, 2012). 
The new methods of active and passive TB case finding based on family and society that are expected to improve TB case findings should be studied further. The implementation of an active discovery strategy has been carried out by screening TB patients through a Desa Siaga program in the district. Strategies in other regions are carried out through partnerships between government and NGOs by fulfilling the principle of equity. The form of sustainability is that the government continues to provide treatment management support, while the Nahdhatul Ulama (NU) Muslim NGO continues the TB control program with a focus on finding partners or donors and establishing community groups concerned with TB (Syafar and Abna, 2017).

West Sulawesi Province as one of the new provinces in Indonesia also implemented the DOTS strategy as an effort believed to be effective on TB control. The effectiveness of DOTS can be determined by health search behavior related to patient demographic characteristics, knowledge about TB, health education and trust (Esmael et al., 2013).

Based on the health profile of West Sulawesi Province, Case Notification Rate (CNR) of TB control is used to be the indicator. It shows the number of new patients found among 100,000 residents in a particular area. This CNR is useful for showing the trend of the TB patient case-finding in a region. The highest acid-fast bacilli (BTA) $(+)$ incident was found in the work area of Malunda Community Health Center (44 cases) and then Banggae I (40 cases), whereas the lowest incident in the work area of Salutambung Health Center (2 cases) (Dinas Kesehatan Kabupaten Majene, 2017).

In addition, it is known that cases of BTA $(+)$ are still found at all the working areas of community health center in Majene. This matter indicates that TB transmission in Majene Regency is still high. For this reason, it is necessary to study and analyze the involvement of health workers and the role of the community in TB case-finding as well as do the interventions in increasing TB knowledge and practices. This research was conducted in Majene Regency also due to it is a district in West Sulawesi that has not implemented a community involvement program, including Global Fund assistance in TB control.

\section{Methods}

The design of this study was quasi-experimental with one group pretest and posttest design. The research was conducted in the work area of Banggae I Community Health Center in Majene. A preliminary study was conducted through a meeting with several village heads, Banggae Sub-District Head, Head of Banggae Health Center and cadres.

The population in this study was the housewives who lived in the area of Banggae I Health Center. The inclusion criterias were housewives who have lived in the village for more than three years, have a family member(s) with potential risk of TB (TB suspect) and have taken part in the intervention activities completely as well as completing the pretest and posttest questionnaires.

Data were collected by questionnaire containing multiple choice types (option A-E). At the first, participants filled out the informed consent then they were given a question sheet that must be filled in according to what they know before the intervention. After that, the participant must answered the same form as before. Pretest and posttest activities were held on the same day. Data collection was carried out by being accompanied and supervised directly by the research team to ensure the question were truly understood by the participants. Over all, there were 33 data were collected. Data were analyzed by paired $T$-test $(p<0.05)$ because it was found that data was normally distributed.

\section{Results}

There were three categories of pretest-posttest questionnaire, namely knowledge about TB information (3 questions), knowledge about advocacy related to TB case-finding and control (8 questions) and knowledge about communication and social mobilization related to TB case-finding and control (12 questions).

Based on the data in Fig. 1, in the category of basic information about $\mathrm{TB}$, it was found that there was an increase in scores on questions regarding the main symptoms of TB and transmission of TB. At the pretest, 18 people $(54.5 \%)$ answered the main symptoms of TB correctly and 9 people $(27.3 \%)$ answered correctly on TB transmission and then increased at the posttest, which was 29 people $(87.9 \%)$ correct about the main symptoms TB and 17 people (51.5\%) correct about TB transmission. There was a decrease in the score on the question of how to know adults suffer from TB, namely $63.6 \%$ at the pretest and $51.5 \%$ at the time of posttest.

In the advocacy category, it is known that there was an increase in scores on most questions. However, there was also a significant decrease in scores on questions related to the criteria of being a TB cadre. At the pretest, there were 21 people $(63.6 \%)$ who answered correctly, but dropped to 9 people $(27.3 \%)$ who answered correctly at the posttest.

In the category of social communication and mobilization, it is known that there was an increase in scores on most questions. The highest increase was shown in the question regarding the effective communication requirements, namely $45.5 \%$ during the pretest and $81.8 \%$ during the posttest, as well as questions about the steps to remind the patient to take the drug and recheck the phlegm, which is $9,1 \%$ at pretest and $33.3 \%$ at posttest. In this category, there was also a decrease in scores on questions related to the target group of counseling, namely $63.6 \%$ during the pretest and $57.6 \%$ during the posttest. 


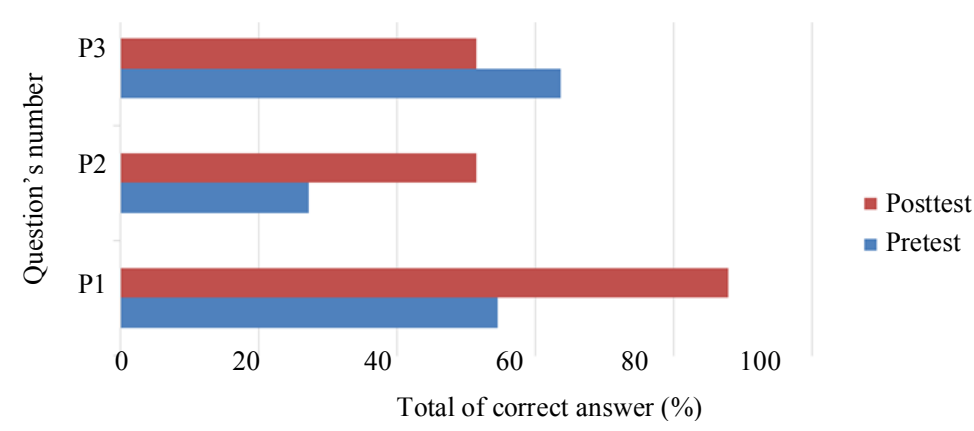

Fig. 1: Comparison of pretest-posttest score based on information category $(\mathrm{P} 1=$ Main symptoms; $\mathrm{P} 2=\mathrm{TB}$ transmission; $\mathrm{P} 3=\mathrm{TB}$ main symptoms in adult)

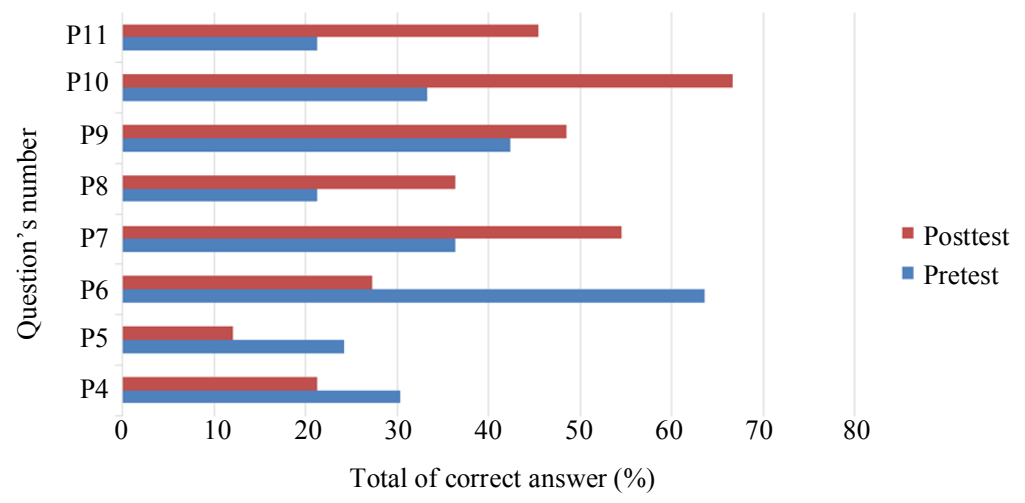

Fig. 2: Comparison of pretest-posttest score based on advocacy category $(\mathrm{P} 4=$ The term of patients drop out of treatment for $\geq 2$ months; P5 = The initial treatment period; P6 = TB cadre criterias; P7 = TB cadre duties; P8 $=$ The steps to remind TB patient to take the medicine and recheck the phlegm; P9 = drugs swallowing controller (PMO) criteria; $\mathrm{P} 10=$ who could be PMO; P11 = PMO duties)

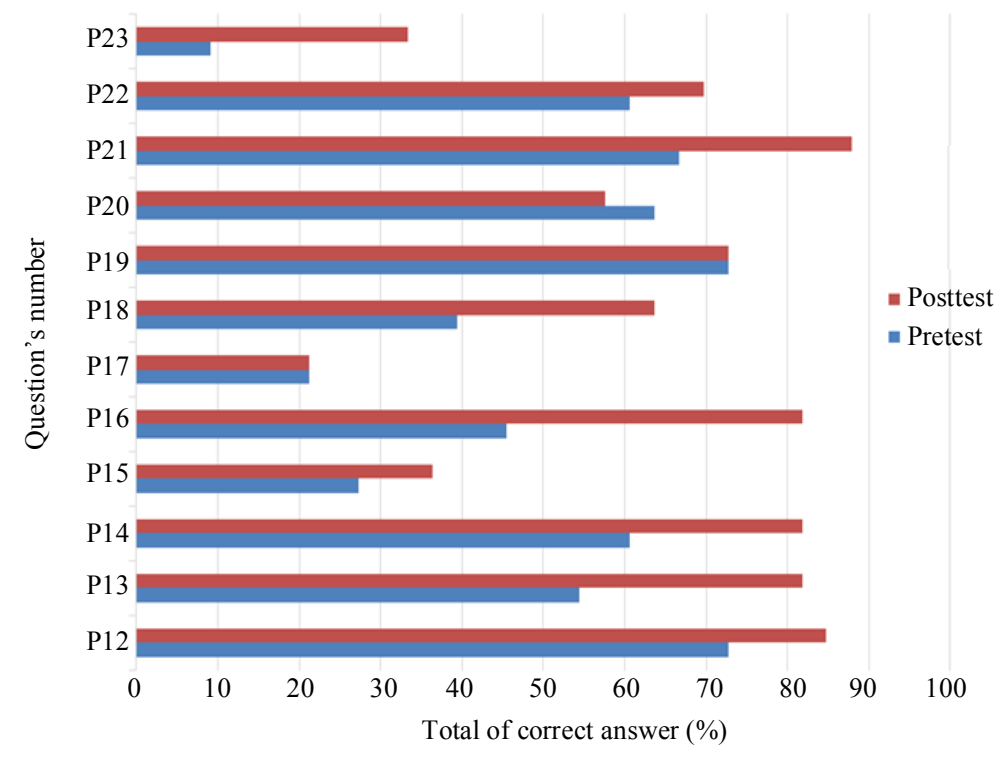

Fig. 3: Comparison of pretest-posttest score based on communication and social mobilization category (P12= The messages that should be told at counseling time with TB patients families or people who live nearby; P13 = The component of communication; P14 = The purpose of interpersonal communication; P15 = How to communicate effectively; P16 = Effective communication requirements; P17 = Effective communication barriers; P18 = The important things in motivating patients; P19 = Location for counseling; P20 = Counseling targets; P21 = Things to do in counseling; P22 = Counseling messages to families and people living nearby; $\mathrm{P} 23$ = Steps to remind the patient to take the medicine and recheck the phlegm) 
Table 1: Paired T-test analysis of pretest and posstest score among intervention participants

\begin{tabular}{lrc}
\hline & Pretest & Posttest \\
\hline $\mathrm{N}$ & 33.000 & 33.00 \\
Minimum & 0.000 & 5.00 \\
Maksimum & 16.000 & 19.00 \\
Mean & 10.120 & 12.76 \\
$\mathrm{SD}$ & 4.020 & 3.42 \\
$p$-value & 0.005 & \\
\hline
\end{tabular}

Based on the data in Fig. 1, 2 and 3, it can be seen that there was an increase in scores pre and post intervention with the most increase happened in the category of knowledge/information as well as communication and social mobilization. There was also a decrease in scores on several questions, especially in the advocacy category.

After the results of the pre and posttest interventions were obtained, further analysis was carried out to determine the minimum value, maximum value, mean, standard deviation and significance value in the study respondents through paired T-test. Data analysis results are shown through the Table 1.

From the Table 1, it can be seen that the average value of respondents at the pretest was 10.12 and when the posttest was 12.76. Based on the results of the paired T-test analysis, the $p$-value $=0.005(p<0.05)$ was obtained. This shows that there are significant differences in the average score of respondents during the pretest and posttest. Thus, it can be concluded that there is an effect of intervention on increasing respondents' knowledge.

\section{Discussion}

Advocacy, communication and social mobilization (ACSM) is a concept as well as an integrated framework for influencing and changing public policies, behavior and empowering the community in implementing TB control (Kementerian Kesehatan RI, 2011). In the National Guidelines for Tuberculosis Management issued by the Indonesian Ministry of Health, the ACSM strategy consists of social mobilization as the spearhead supported by communication and advocacy efforts. The three strategies are integrated with enthusiasm and directed so that the community is able to practice TB prevention and treatment behavior.

The results showed that in the knowledge /information category questions, there was an increase in scores on questions regarding the main symptoms of TB and transmission of TB. In the pretest, most respondents answered that TB transmitted through salivary TB patients where this statement is still not appropriate. After the posttest was conducted, most of the respondents had answered precisely that TB transmission could occur through the sputum of the sufferer. Basic information related to symptoms, transmission and identification of TB patients is an important thing that is needed for each supporter of TB patients. The knowledge of this information forms the attitudes and behavior of patients and officers/support groups since the diagnosis, treatment and post-treatment stages (Kementerian Kesehatan RI, 2011).

Advocacy in the TB control ACSM is a strategic and planned effort or process to get commitment and support from all stakeholders (Kementerian Kesehatan RI, 2011). Regarding the advocacy category in the pre and posttest intervention questions, it was found that there was an increase in scores on most questions. However, it should also be noted that there was a decrease in scores on several questions. Decrease in scores occurred in questions about the definition of the group of treatment patients after dropping out of treatment, the period of the initial stage of treatment in TB patients and TB cadre criteria. In this case, there are still respondents who are not right in formulating TB cadre criteria. TB cadre criteria are someone who is known, trusted and approved not only by officers, but also by TB patients themselves (Kementerian Kesehatan RI, 2011).

Communication in the TB control ACSM is an effort to create an opinion or social environment that encourages the general public and health workers to be willing to jointly tackle TB transmission. Social mobilization in the process of giving information continuously and continuously following the development of goals and the process of helping the target so that the target has the knowledge, attitudes and practices of the expected behavior (Kementerian Kesehatan RI, 2011). Knowledge of health workers about the ACSM TB program is important because the low level of knowledge of health workers about the TB ACSM program can be a cause of the ACSM program not being implemented (Moulina et al., 2018).

In improving the function of social support for $\mathrm{TB}$ sufferers, aspects of communication and social mobilization are a series that need attention. As discussed in the review, effective communication in this case motivational communication has a patientcentered principle. Therefore, the support group must know the target group of their counseling correctly regarding TB control.

In research related to the role of health communication among the poor, there are two models of communication carried out by TB Care 'Aisyiyah in the TB control program. The communication intervention uses monological and dialogical communication and is also supported by the sincerity of cadres and PMOs. Further results show that the success of TB community also depends on interpersonal communication and participation of volunteers, community leaders and PMOs (Syarah et al., 2014). Communication in counseling also contributes to people's knowledge regarding the prevention of tuberculosis in Suppa Subdistrict, Pinrang (Kadir, 2010). 
In general, the results of this study also show that there are significant differences in the average score of respondents during pre and posttest. It was concluded that there was an influence of intervention on increasing respondents' knowledge regarding basic information about $\mathrm{TB}$, advocacy, communication and social mobilization.

The increase in knowledge, attitudes and skills related to TB control was also proven in several previous studies. The research conducted by Yanti (2016) in the TB care cadre group (KKP-TB) showed that there was an increase through KKP-TB training activities by discussing three topics, namely TB-related basic information, cadre skills in group and family counseling and mentoring of cadres in do family counseling. In addition, the presence of TB care groups can also strengthen TB control programs in the community (Yanti, 2016). The training to increase knowledge about the treatment of TB in the cadre of the FK UMSU-assisted family work area as part of the ACSM effort also proved effective even though better preparation was needed regarding the modules read and studied by cadres (Boy, 2015).

Not only in the cadre group, changes in knowledge and attitudes related to TB due to intervention also occurred in the adolescent group. This was demonstrated through quasi-experimental research conducted on YP Singosari High School Deli Serdang students by comparing control groups and intervention groups. The intervention method is done through a peer health counseling group model (Purba and Ferabetty, 2018).

\section{Conclusion}

The intervention activities carried out proved to be influential on increasing knowledge about TB information, advocacy efforts, as well as communication and social mobilization efforts related to TB casefinding, prevention and control in housewives at the working area of Banggae I Health Center, Majene District, West Sulawesi. However, there was a decrease in scores on several questions related to advocacy efforts in TB control. Thus, further training is recommended with a focus on TB prevention advocacy efforts and training to improve communication-related skills to the TB patients.

\section{Acknowledgement}

We would like to express our gratitude to the Head of Banggae I Community Health Center and staffs as well as the head of village who helped us doing the research processes. We also thank the Research and Community Development Center of Universitas Hasanuddin for facilitating the fund of this research.

\section{Author's Contributions}

Muhammad Syafar: Designed the research plan, organized the study, participated in all research processes, cordinated the data-analysis and manuscript writing.
Muhammad Ikhsan: Designed the research plan, organized the study, participated in the intervention activities.

Indra Fajarwati Ibnu: Designed the research plan and organized the study.

Rachma Rahim: Analyzed the data and manuscript writing.

\section{Ethics}

The aims and objectives of the study was discussed with head of the community health center and staffs. All the participants signed the informed consent forms prior to enrolment in the study. They were also being briefed and offered the opportunity to ask questions about the study. The written consent forms and participant information form were kept separately from the data collections tools.

\section{References}

Ayles, H., M. Muyoyeta, E.D. Toit, A. Schaap and S. Floyd et al., 2013. Effect of household and community interventions on the burden of tuberculosis in Southern Africa: The ZAMSTAR community-randomised trial. Lancet, 382: 1183-1194. DOI: $10.1016 / \mathrm{S} 0140-6736(13) 61131-9$

Balitbangkes RI, 2013. Riset Kesehatan Dasar 2013. Jakarta: Kementerian Kesehatan RI.

Boy, E., 2015. Efektivitas Pelatihan Kader Kesehatan dalam Penanganan Tuberkulosis di Wilayah Binaan. J. Pendidik. Kedokt. Indones., 4: 83-89.

Dinas Kesehatan Kabupaten Majene, 2017. Profil Kesehatan Kabupaten Majene Tahun 2016. Majene: Dinkes Kabupaten Majene.

Esmael, A., I. Ali, M. Agonafir, A. Desale and Z. Yaregal et al., 2013. Assessment of patients' knowledge, attitude and practice regarding pulmonary tuberculosis in Eastern Amhara Regional State, Ethiopia: Cross-Sectional Study. Am. J. Trop. Med. Hyg., 88: 785-788.

Kadir, A., 2010. Peranan Komunikasi Melalui Penyuluhan terhadap Pengetahuan dan Kemampuan Masyarakat dalam Penanggulangan Tuberkulosis di Kabupaten Pinrang. Universitas Hasanuddin.

Kementerian Kesehatan RI, 2011. Pedoman Nasional Pengendalian Tuberkulosis. Jakarta: Kementerian Kesehatan RI.

Kementerian Kesehatan RI, 2011. Rencana Aksi Nasional Advokasi Komunikasi dan Mobilisasi Sosial Pengendalian Tuberkulosis Indonesia: 2011-2014. Jakarta: Kementerian Kesehatan RI.

Kementerian Kesehatan RI, 2015. Profil Kesehatan Indonesia 2014. Jakarta: Kementerian Kesehatan RI.

Moulina, T.E., Yuwono and R. Taqwa, 2018. Studi Kualitatif Implementasi Advokasi, Komunikasi, dan Mobilisasi Sosial dalam Pengendalian Tuberkulosis Paru di Kabupaten Musi Rawas Utara Tahun 2016. JKK, 5: 38-48. 
Myint, O., S. Saw, P. Isaakidis, M. Khogali and A. Reid et al., 2017. Active case-finding for tuberculosis by mobile teams in Myanmar: Yield and treatment outcomes. Biomed. Cent. Infect. Dis. Poverty, 6: 1-8.

R. Purba and Y. Ferabetty, 2018. Pengaruh Penyuluhan Kesehatan Model Peer Group terhadap Pengetahuan dan Sikap Remaja tentang Tuberkulosis Paru. J. Penelit. Keperawatan Med., 1: 32-36.

Sumartini, N.P., 2014. Penguatan Peran Kader Kesehatan dalam Penemuan Kasus Tuberkulosis (TB) BTA Positif Melalui Edukasi dengan Pendekatan Theory of Planned Behaviour (TPB). J. Kesehat. Prima, 8: 1246-1263.

Sutarno and G.A. Utama, 2012. Faktor-Faktor yang Memengaruhi Motivasi Berobat Penderita Tuberkulosis di Kota Pekalongan Tahun, pp: 6686.

Syafar, M. and N.J. Abna, 2017. Kemitraan Pemerintah dengan Muslimat NU (NGO) dalam Pengendalian Tuberkulosis Paru. Media Kesehat. Masy. Indones., 13: 281-288.
Syarah, M.M., S. Sarwoprasodjo and R.W.E. Lumintang, 2014. Peran Komunikasi Kesehatan pada Kalangan Masyarakat Miskin. Makara Hubs-Asia, 18: 149-158.

WHO, 2018. Global Tuberculosis Report 2018. Geneva: World Health Organization.

Yanti, N.L.P.E. 2016. Pengendalian Kasus Tuberkulosis Melalui Kelompok Kader Peduli TB (KKP-TB). Nursing Program, School of Medicine, Udayana University, pp: 75-80.

Zachariah, R., M.P. Spielmann, A.D. Harries, P. Gomani and S.M. Graham et al., 2003. Passive versus active tuberculosis case finding and Isoniazid preventive therapy among household contacts in a rural district of Malawi. Int. J. Tuberc. Lung Dis., 7: 1033-1039. 